\title{
A Histochemical Study of the Mature Test Plate and the Peristomial Membrane in a Sea Urchin
}

\author{
Motohiro SHIMIZU* and Jyo TAKI** \\ (Received March 27, 1972)
}

\begin{abstract}
Histotopographical observations of collagen-like fibers and other organic substances in the mature test plate and the associated tissues of a sea urchin were recently carried out. The collagen-like fibers, complicated with acid mucopolysaccharides, PAS-positive materials, non-fibrous proteins and sudanophilic substances, were found to occur in actively growing areas of the test plate, the spine muscle and the peristomial membrane, whereas no such fibers could be found in the mid-portion of the test plate and the calcified areas of the peristomial membrane. A seasonal difference in the histochemical nature of the above organic substances was not detected.
\end{abstract}

Very little has been known of the histotopography of organic substances in the test plate of sea urchins. OKAZAKI ${ }^{1)}$ suggested that the organic matrix is a prerequisite for the spicule formation in sea urchin larvae on the basis of her finding that calcite crystals are embedded in the organic matrix. Is OKAZAKI's concept applicable immediately to the mineralization of the mature test plate? In an electron microscope study of Strongylocentrotus droebachiensis and Lytechinus variegatus, TRAvis et al. ${ }^{2}$ detected evidence that collagen fibers similar to typical mammalian ones form the organic matrix of mature test plates in which the calcification occurs. However, Moss and $\mathrm{MEEHAN}^{3}$ have not thought of sutural and other dermal collagen-like fibers, embedded in acid mucopolysaccharide-rich matrix, as calcifiable tissue elements in Arbacia and other echinoderms. KOBAYASHI and TAKI ${ }^{4}$ clarified, in their tetracycline labeling study of Strongylocentrotus intermedius, that the active growth takes place in the sutural area and that the fibrous elements in that area may participate in the occurrence of the growth gradient of the test.

Collagen fibers, acid mucopolysaccharide-protein complexes, and lipids have been known to be important organic components in initiating the mineralization of various hard tissues ${ }^{5)}$. However, it is not clear at present in what state those organic substances exist in the test plate and what roles they play in the test growth. From such a point of view, the histotopographical distribution of organic substances such as fibrous elements, mucopolysaccharides, proteins, and lipids in the decalcified test plate and the peristomial membrane has been examined in this study.

\footnotetext{
* Faculty of Fisheries, Hokkaido University, Hokadate, Japan (清水幹博：北海道大学水産学部)

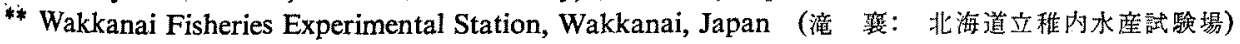




\section{Material and Methods}

About sixty sea urchins, Strongylocentrotus intermedius, $31-100 \mathrm{~g}$ in body weight and $3-7 \mathrm{~cm}$ in test diameter, were used as material. These specimens were collected throughout the year at a frequency of 4-12 individuals per month, at littoral areas near Hakodate. According to ecological studies by previous workers ${ }^{6-9)}$, these specimens were estimated to be aged at more than three years.

The fresh tests were cut into pieces through the use of an electric dental engine so as to include both the spine muscle and the sutural area in each piece. The pieces of the test plates thus obtained together with the simultaneously removed peristomial membrane were treated as follows. The fixatives used were: 10\% neutral formalin for von KosSA stain, Helly's fluid for mainly azan stain, CARNOY's fluid for periodic acid-Schiff reaction, $1 \%$ cetylpridinium chloride in either $5 \%$ formalin or $4 \%$ glutaraldehyde for acid mucopolysaccharides, and MCMANus's method for lipids ${ }^{10)}$.

Most of the fixed tissue pieces were immersed in cold $5 \%$ disodium ethylendiaminetetraacetate (EDTA-Na) solution containing either $5 \%$ formalin or $4 \%$ glutaraldehyde, final $\mathrm{pH}$ adjusted to 7.4 with $0.1 \mathrm{~N}$ sodium hydroxide, until the decalcification was completed. With the use of CARNOY's fluid, the fixed tissues were decalcified with $5 \%$ trichloroacetic acid in $90 \%$ ethanol.

The following staining and histochemical techniques were applied to paraffin sections cut at 4-10 $\mu$ in thickness: 1. Haematoxylin and eosin; 2. voN KossA's for calcium salts; 3. Azan, VAN GIESON's picro-fuchsion, WEIGERT's resolcin-fuchsin ${ }^{11}$, polychrome ${ }^{12)}$, and Humason's stains ${ }^{13)}$, some accompanied with the digestion with $1 \%$ pepsin and $1 \% \operatorname{trypsin} ; 4$. Metachromatic reactions with toluidine blue $(\mathrm{pH}$ $2.5)^{14)}$ and methylene blue ( $\mathrm{pH} 2.5$ ), alcian blue stain $(\mathrm{pH} \mathrm{1.0,} \mathrm{and} \mathrm{2.5)} \mathrm{after} \mathrm{ScotT} \mathrm{et}$ $a .^{15)}$, and colloidal iron stain according to MüLLER's method ${ }^{14)}$ for acid mucopolysaccharides; the digestion with $1 \%$ testicular hyaluronidase (Worth. Biochem. Co.) prior to some of these stainings, and the methylation and saponification test according to FISHER and LILLIE's method ${ }^{14}$; metachromatic reaction with toluidine blue (pH 3.4) containing heavy metal ions ${ }^{14)}$; pretreatment with pyridin $\left(60^{\circ} \mathrm{C}, 2448\right.$ hours $)$ in order to remove lipids in metachromatic reactions; 5. Periodic acid-Schiff (PAS) reaction accompanied with the digestion test by $1 \%$ amylase (Wako Pure Chem. Ind.) ${ }^{28}$ and acetylation and saponification test after MCMANUS and CASON's method ${ }^{14)}$ for PASpositive metarilas; 6. Mercuric chloride-bromophenol blue (Hg-BPB) $\operatorname{stain}^{17}$, and ninhydrine-Schiff reaction ${ }^{14)}$ for proteins; 7. Sudan black B stain according to MCMANUS $^{10)}$ for lipids, contrasted with hot pyridin- ${ }^{18)}$ and hot chloroform-methanoltreated preparations $\left(60^{\circ} \mathrm{C}, 24-48\right.$ hours). Among the above mentioned procedures, deamination and digestion with $1 \%$ trypsin or pepsin were applied in some preparations 
to examine whether or not the mucosubstances are complexed with proteins.

Microradiographic observations of the test plates and the peristomial membrane were made on trabeculae in the fenestrate structure.

The intact and decalcified pieces of the test plates were embedded in Epon, cut at $1 \mu$ in thickness, stained with toluidine blue and the topographical relationship between the trabeculae and the organic substances was observed.

\section{Observations}

Implication of skeletal pillars and organic substances: The test of the sea urchin is composed of the epidermis and the dermis, the latter is largely replaced with calcareous plates. The microradiography of a transverse section of the test plate shows pillars of skeletal elements, or trabeculae, arranged compactly in areas close to the suture, the inner and the outer surfaces, and in the tubercle area (Fig. 1). The pillars in the area close to the inner surface are considerably thicker than those in other areas. On the other hand, those of the mid-portion distant from both the outer and the inner surfaces and of the region just contiguous to the suture are found to be thinner and arranged loosely.

The mineralized pillars are represented as emptied "holes" in an Epon-section of the decalcified test plate (Fig. 2). They are confused with each other to form a fenestrate structure surrounded by a stereomal organic framework which is mainly composed of fibrous and cellular elements. The fibrous elements are particularly abundant in the sutural area. Almost no organic substances are detected in the "holes". In comparison with the microradiograph, it is understood that the organic substances of the framework, filling the interstices of the highly mineralized skeletal pillars, are not mineralized.

There are many small calcified areas scattered in the peristomial membrane. These calcified islands are constructed with the trabeculae and the organic framework as is the mid-portion of the test plate, while the remaining non-calcified part of the membrane is occupied with abundant fibrous bundles (Fig. 3).

Histotopographical evidence of fibrous elements: The fibrous elements found in the test plate and the associated tissues show staining behaviours similar to those of collagen fibers vertebrates as revealed by azan and VAN GIESON's picro-fuchsin stains. However, slightly different sensitivities in WEIGERT's resolcin-fuchsin, polychrome, Humason's stains, and digestion with pepsin were observed between the two kinds of fibers.

The fibrous elements occur in: 1) the sutural area; 2) the outer and the inner surfaces of the dermis; 3) the inner layer of the spine muscle (Fig. 4); and 4) the non-calci- 
Table 1. Histological characteristics of the collagen-like fibers and

\begin{tabular}{|c|c|c|c|}
\hline & \multicolumn{3}{|c|}{ Test plate } \\
\hline & Suture & $\begin{array}{c}\text { Inner and Outer } \\
\text { surfaces }\end{array}$ & Mid-portion \\
\hline Haematoxylin and eosin & purple & purple & $\begin{array}{l}\text { weak purple } \\
\text {-unstained }\end{array}$ \\
\hline Azan & deep blue & blue & $\begin{array}{l}\text { weak blue } \\
\text {-unstained }\end{array}$ \\
\hline van Gieson's picro-fuchsin & bright red & red & $\begin{array}{l}\text { red } \\
\text {-weak red }\end{array}$ \\
\hline Weigert's resolcinfuchsin & $\begin{array}{l}\text { weak blackish } \\
\text { blue }\end{array}$ & $\begin{array}{l}\text { weak blackish } \\
\text { blue }\end{array}$ & unstained \\
\hline Polychrom & blue & blue & $\begin{array}{l}\text { very weak blue } \\
\text {-unstained }\end{array}$ \\
\hline Humason's selective stain & $\begin{array}{l}\text { deep brownish } \\
\text { blue }\end{array}$ & $\begin{array}{l}\text { brownish } \\
\text { blue }\end{array}$ & weak brown \\
\hline \multicolumn{4}{|l|}{ Digestion } \\
\hline by trypsin & relatively slow & relatively slow & rapid \\
\hline by pepsin & relatively rapid* & relatively rapid & relatively slow \\
\hline
\end{tabular}

* A longer time was required for the complete digestion of fibers compared with that of mammalian,

fied connective tissue of the peristomial membrane (Fig. 5). In the sutural systems; both longitudinal (zig-zag) and latitudinal (straight), abundant bundles of fine collagenlike fibers extend over the adjacent test plates (Fig. 6). Such abundant fibers in the form of compact bundles are also detected in the inner layer of the spine muscle (Fig. 4) and in the non-calcified connective tissue of the peristomial membrane (Fig. 5), whereas those in both the outer and the inner surfaces of the dermis are found to lie forming rather loose bundles.

No such collagen-like fibers were noticed in either the mid-portion of the dermis or the calcified area of the peristomial membrane (Figs. 7 and 8). These areas display a typical reticulous structure composed of thin organic substances and cellular elements. The thin organic substances appear occasionally to be fibrous and show very weak stainabilities in several stainings (Table 1).

Histochemical nature of the collagen-like fibers and the reticulous structure: The collagen-like fibers showed metachromatic reactions with both toluidine blue and methylene blue at low pH (Fig. 9). These metachromasia never disappeared through dehydration though some decrement in color intensity was observed during the process of dehydration with tert.-buthyl alcohol. Both alcian blue and colloidal iron stained these fibers positively. As indicated in Table 2, no distinct difference was found between the metachromatic reactions with toluidine blue containing heavy metal ions and with that lacking such ions. The metachromasia with toluidine blue and methylene blue and the stainings with alcian blue and colloidal iron were recovered on the fibers after the saponification procedure for methylated preparations, although the intensities were somewhat reduced compared with the intact control preparations. Digestion 
the reticulous structure in the test plate and the associated tissues

\begin{tabular}{|c|c|c|c|}
\hline \multicolumn{2}{|c|}{ Spine muscle } & \multicolumn{2}{|c|}{ Peristomial membrane } \\
\hline Inner layer & Outer layer & Calcified area & Non-calicfied area \\
\hline deep purple & pinkish red & $\begin{array}{l}\text { weak purple } \\
\text {-unstained }\end{array}$ & deep purple \\
\hline deep blue & red & $\begin{array}{l}\text { weak blue } \\
\text {-unstained }\end{array}$ & deep blue \\
\hline bright red & yellow & weak red & bright red \\
\hline weak blackish blue & unstained & unstained & weak blackish blue \\
\hline blue & greenish yellow & $\begin{array}{l}\text { very weak } \\
\text { blue-unstained }\end{array}$ & blue \\
\hline deep brownish blue & deep red & $\begin{array}{l}\text { weak brown } \\
\text {-unstained }\end{array}$ & deep brownish blue \\
\hline $\begin{array}{l}\text { relatively slow } \\
\text { relatively rapid* }\end{array}$ & $\begin{array}{l}\text { rapid } \\
\text { very slow }\end{array}$ & $\begin{array}{l}\text { rapid } \\
\text { relatively slow }\end{array}$ & $\begin{array}{l}\text { relatively slow } \\
\text { relatively rapid* }\end{array}$ \\
\hline
\end{tabular}

with hyaluronidase also reduced the reactivities. On the other hand, the deamination for 24 hours or with either trypsin and/or pepsin caused somewhat more intense reactions (Fig. 10). The reticulous structure of thin organic substances in both the midportion of the dermis and the calcified area of the peristomial membrane showed no distinct evidence of any acid mucopolysaccharides. After deamination, however, weakly positive reactions for acid mucopolysaccharides were detected.

The collagen-like fibers were observed to react for the PAS. Their PAS-positivity was relatively intense in the suture (Fig. 11), the inner layer of the spine muscle and the peristomial membrane (Fig. 12). It was not affected by digestion with amylase and it recovered after the saponification for acetylated preparations. The reticulous structures in both the mid-portion of the dermis and the calcified area of the peristomial membrane (Figs. 11 and 12) showed a feeble PAS-positive reaction. Occasionally, strong PAS-positive granules were found to lie scattered in the reticulous structure. Deamination for 24 hours did not affect the PAS-positivity of the granules but reduced that of the collagen-like fibers (Fig. 13).

The proteinaceous nature of the collagen-like fibers was examined by the $\mathrm{Hg}-\mathrm{BPB}$ (Fig. 14) and the ninhydrine-Schiff reactions. The most intense stain or reaction was obtained on the outer layer of the spine muscle which possibly consists of smooth muscle fibers, whereas the collagen-like fibers reacted less intensely. After deamination for 24 hours, the intensities of both the collagen-like fibers and the smooth muscle fibers decreased considerably. The reticulous structure, except the cellular elements, of both the mid-portion of the dermis and the calcified area of the peristomial membrane showed a very weak reactivity for proteins (Fig. 15). 
Table 2. Histochemical characteristics of the collagen-like fibers and

\begin{tabular}{|c|c|c|c|}
\hline & \multicolumn{3}{|c|}{ Test plate } \\
\hline & Suture & $\begin{array}{c}\text { Inner and Outer } \\
\text { surfaces }\end{array}$ & Mid-portion \\
\hline Metachromasia with TB (pH 2.5) & 2 & $2-1$ & $\mathbf{N}-$ Ort \\
\hline after $M \& S$ & 1 & $1-\mathbf{N}$ & $\mathbf{N}$ \\
\hline H-ase & $1-N$ & $1-N$ & $\mathbf{N}$ \\
\hline trypsin and/or pepsin & 2 & $2-1$ & $\mathbf{N}$ \\
\hline deamination & 3 & 2 & 1 \\
\hline \multicolumn{4}{|l|}{$\begin{array}{l}\text { Metachromasia with TB (pH 3.4) } \\
\text { containing }\end{array}$} \\
\hline $2 \mathrm{mEq} \mathrm{UO}_{2}\left(\mathrm{NO}_{3}\right)_{2}$ & 2 & $2-1$ & $\mathbf{N}$ \\
\hline $2 \mathrm{mEq} \mathrm{Ba}\left(\mathrm{NO}_{3}\right)_{2}$ & 2 & $2-1$ & $\mathbf{N}$ \\
\hline $100 \mathrm{mEq} \mathrm{Ba}\left(\mathrm{NO}_{3}\right)_{2}$ & 2 & $2-1$ & $\mathbf{N}$ \\
\hline Metachromasia with $\mathrm{MB}$ (pH 2.5) & 2 & $2-1$ & N-Ort \\
\hline Alcian blue (pH 2.5 and 1.0 ) & 2 & $2-1$ & $1-\mathrm{N}$ \\
\hline after $\mathrm{M} \& \mathrm{~S}$ & 1 & 1 & 1 \\
\hline H-ase & 1 & 1 & $\mathbf{N}$ \\
\hline trypsin and/or pepsin & 2 & $2-1$ & $1-N$ \\
\hline deamination & $3-2$ & 2 & 1 \\
\hline Colloidal iron & 2 & 2 & $1-\mathbf{N}$ \\
\hline after $\mathrm{M} \& \mathrm{~S}$ & $2-1$ & 1 & $1-N$ \\
\hline H-ase & 1 & $1-N$ & $\mathrm{~N}$ \\
\hline PAS-reaction & 2 & 1 & 1 \\
\hline after A \& S & 2 & 1 & 1 \\
\hline A-ase & 2 & 1 & 1 \\
\hline deamination & 1 & $1-N$ & $1-\mathrm{N}^{*}$ \\
\hline $\mathrm{Hg}-\mathrm{BPB}$ & $\begin{array}{l}\text { reddish blue } \\
\text {-bluish geen }\end{array}$ & $\begin{array}{l}\text { bluish green } \\
\text {-green }\end{array}$ & green-yellow \\
\hline after deamination & yellow green & yellow green & yellow-N \\
\hline Nynhydrin-Schiff & 2 & $2-1$ & $1-\mathrm{N}$ \\
\hline Sudan black B & 1 & 1 & $\mathbf{N}$ \\
\hline after Py and/or C-M & 1 & 1 & $\mathrm{~N}$ \\
\hline
\end{tabular}

TB: toluidine blue; $\mathrm{MB}$ : methylene blue; $\mathrm{M} \& \mathrm{~S}$ : methylation and subsequent saponification; trypsin and/or pepsin; A \& S: acetylation and subsequent saponification: A-ase: digestion with orthochromasia Intensities were indicated by: 3(strong), 2 (moderate), 1 (weak), $N$ (negative).

* Strong PAS-positive granules were occasionally found.

Sudanophilic substances revealed by sudan black B were found on both the collagenlike fibers and the smooth muscle fibers in the outer layer of the spine muscle (Fig. 16). The reticulous structure, except the cellular elements, was shown to be negative. The stainability of the collagen-like fibers was not reduced even after extracting lipids by pyridin or chloroform-methanol for 48 hours (Fig. 17).

No seasonal differences in the histochemical nature of the above organic substances were detected in the test plate and the peristomial membrane. 
the reticulous structure in the test plate and the associated tissues

\begin{tabular}{|c|c|c|c|}
\hline \multicolumn{2}{|c|}{ Spine muscle } & \multicolumn{2}{|c|}{ Peristomial membrane } \\
\hline Inner layer & Outer layer & Calcified area & Non-calcified area \\
\hline 2 & $\mathbf{N}$ & $\mathbf{N}$ & 2 \\
\hline 1 & $\mathbf{N}$ & $\mathbf{N}$ & 1 \\
\hline $1-N$ & $\mathbf{N}$ & $\mathbf{N}$ & 1 \\
\hline 2 & $N$ & $1-N$ & 2 \\
\hline 3 & 1 & 1 & $3-2$ \\
\hline 2 & $\mathbf{N}$ & $\mathbf{N}$ & 2 \\
\hline 2 & $\mathbf{N}$ & $\mathbf{N}$ & 2 \\
\hline 2 & $\mathbf{N}$ & $\mathbf{N}$ & 2 \\
\hline 2 & N-Ort & $\mathbf{N}$ & 2 \\
\hline 2 & $1-N$ & $1-N$ & 2 \\
\hline 1 & $\mathrm{~N}$ & $\mathbf{N}$ & 1 \\
\hline 1 & $\mathrm{~N}$ & $\mathrm{~N}$ & 1 \\
\hline 2 & $1-N$ & $1-N$ & 2 \\
\hline 3 & 1 & 1 & $3-2$ \\
\hline 2 & 1 & $1-\mathrm{N}$ & 2 \\
\hline $2-1$ & $\mathrm{~N}$ & $\mathrm{~N}$ & 1 \\
\hline 1 & $\mathbf{N}$ & $\mathbf{N}$ & 1 \\
\hline 2 & $1-N$ & 1 & 2 \\
\hline 2 & 1 & 1 & 2 \\
\hline 2 & 1 & $\mathbf{N}$ & 2 \\
\hline 1 & $\mathrm{~N}$ & $1-N^{*}$ & 1 \\
\hline $\begin{array}{l}\text { reddish blue } \\
\text {-bluish green }\end{array}$ & reddigh blue & green-yellow & $\begin{array}{l}\text { reddish blue } \\
\text {-bluish green }\end{array}$ \\
\hline yellow green & bluish green & yellow-N & yellow green \\
\hline 2 & $3-2$ & 1 & 2 \\
\hline 1 & $3-2$ & $\mathrm{~N}$ & 1 \\
\hline 1 & 1 & $\mathbf{N}$ & 1 \\
\hline
\end{tabular}

H-ase: digestion with $1 \%$ testicular hyaluronidase; trypsin and/or pepsin: digestion with $1 \%$ $1 \%$ amylase; Py and/or C-M: extraction with hot pyridin and/or chloroform-methanol; Ort:

\section{Discussion}

Evidence for the presence of collagen-like fibers and muco substances: The collagenlike fibers of the test plate and the associated tissues showed histological characteristics somewhat different from those of typical, mature collagen fibers in vertebrates (Table 1). Similar results have been reported by several workers. MOSS and MEEHAN ${ }^{3)}$ reported an elastin-positive reaction in the sutural connective tissue of Arbacia. Also, MARK et al. ${ }^{19)}$ showed in their X-ray diffraction study of Asterius and Arbacia the presence of a collagentype protein that is different from the collagen of vertebrates based on its small diffraction order. Travis ${ }^{20)}$, on the other hand, in a recent electron microscope study of $S$. droebachiensis, has found collagen fibers very similar to typical mammalian ones in 
the organic matrix of the test plate. In considering histological behaviours presented in Table 1, it is supposed that the collagen-like fibers are possibly constituted of mature and immature collagen fibers with some non-collagenous fibrous proteins.

Similar to typical collagen fibers, the collagen-like fibers in the sea urchin likewise should reveal a complicated composition with acid mucopolysaccharides, PAS-positive materials and sudanophilic substances. The acid mucopolysaccharides may be classified into two groups based on the metachromasia, alcianophilia, and colloidal iron positivity i.e., the non-sulfated such as hyaluronic acid and the sulfated such as chondroitin sulfates and keratan sulfate. The metachromasia resistant to alcohol and heavy metal ions may suggest the presence of the sulfated groups. Further, positive reactions after both the saponification for methylated preparations and the digestion with $1 \%$ hyaluronidase prove the coexistence of both the sulfated and the non-sulfated acid mucopolysaccharides. A higher reactivity after the deamination suggests that they are in combination with non-fibrous proteins to form a protein-polysaccharides complex. The occurrence of such complex has been well known in various hard tissues of many other animals ${ }^{21-26)}$.

Taking the positive reactions for proteins into consideration, the amylase-resistant PAS-positive materials may be a neutral polysaccharide-protein complex ${ }^{27,28)}$. This complex may also contain an acid glycoprotein such as sialic acid $^{26)}$.

Sudanophilic substances resistant to the extractions with both pyridin and chloroform-methanol may not certainly be simple lipids nor phospholipids ${ }^{18,29}$. They may be complicated with non-fibrous proteins and combined tightly to the collagen-like fibers. ${ }^{30}$

Relationship between the distribution of collagen-like fibers and the test growth: The collagen-like fibers combined with mucosubstances have been detected in actively growning areas of the test plate ${ }^{4)}$. This suggests some roles of such fibers in connection with the test growth. In general, sulfated mucopolysaccharides are known to be capable of combining with calcium ions ${ }^{31}$. Sudanophilic substances or lipids can also bind calcium ions ${ }^{18)}$. Therefore, these substances in association with collagen fibers have been thought to be a nucleating entity in initiating mineralization. Evidenced by a loss or depolymerization of the sulfated mucopolysaccharides just prior to the calcification of cartilages, chondroitin sulfate has been considered to have an inhibitory effect in biological calcification ${ }^{\tilde{5})}$. Recent experimental evidence seems to show that the protein-polysaccharides complex permits the accumulation of calcium near the seeding site in mineralization, but does not allow its sedimentation ${ }^{32}$.

In the sea urchin, it is possible that calcium ions are accumulated in the mucosubstances that are associated with the collagen-like fibers. Possibly by some cellular activity to decompose the protein-polysaccharides complex, these calcium ions may deposit 
subsequently forming calcite crystals into the spaces just contiguous with the organic framework. These spaces may develop into "holes" as the crystals grow up. Accordingly, the formation of the organic framework is required for the growth of trabeculae. This assumption is supported by the fact that the trabeculae are observed to be limited only in the portion having the framework structure. The cellular elements in the test plate and the calcified area of the peristomial membrane may participate in the formation of organic framework and in the primary deposition of calcium salts as it has been reported in the spicule formation in larval stage ${ }^{1,33}$ and in the regenerating tissue ${ }^{34)}$.

However, histotopographical evidence of the collagen-like fibers and the associated mucosubstances alone is not sufficient to elucidate the mechanism of the test growth. Further study should be needed for the nature of cellular elements found in the test plate and the peristomial membrane.

\section{Acknowledgement}

We wish to express our cordial gratitude to Emeritus Professor Shinjiro Kobayashi and Professor Juro YAmada of the Faculty of Fisheries, Hokkaido University, not only for their kind advice in the course of the present study, but also for the revison of the manuscript. We are also indebted to Mr. Husao UMI of the Toi Town Office in the collection of living animals.

\section{References}

1) K. OKAZAKI: Embryologia, 7, 21-38 (1962).

2) D. F. Travis, C. J. Françots, L. C. BonaR and M. J. Glimcher: J. Ultrastr. Res., 18, 519-550 (1967).

3) M. L. Moss and M. M. Meeman: Acta Anat., 66, 279-304 (1967).

4) S. KoBaYASHI and J. TAKI: Calc. Tiss. Res., 4, 210-223 (1969).

5) S. M. WeimmanN: in "Internat. Rev. Conn. Tiss. Res." (D. A. Hall ed.), Vol. 1, 339-377 (1963).

6) A. Fun: Bull. Fac. Fish. Hokkaido Univ., 11, $43-48$ (1960).

7) K. Kawamura: Sci. Rep. Hokkaido Fish. Exp. State., 6, 56-61 (1966).

8) A. Fus: Memor. Fac. Fish. Hokkaido Univ., 15, 83-160 (1967).

9) E. F. SwaN: in "Physiology of Echinodermata" (R. A. Booloorian ed.), 397-434, John Wiley \& Sons, N. Y., London, Sydney (1969).

10) J. F. A. Mcmanus: J. Path. Bact., 58, 93-95 (1946).

11) A. G. E. Pearse: Histochemistry, 2nd ed., J. \& A. Churchill Ltd., London (1960).

12) C. HerovicI: Stain Tech., 38, 204-205 (1963).

13) G. L. Humason and C. C. Lushbaugh: ibid., 35, 209-214 (1960).

14) L. Lison: Histochimie et Cytochimie Animales, $3^{e}$ éd., Gauthier-Villars \& Co., Paris (1960).

15) J. E. Scott, G. Quntarelli and M. C. Dellovo: Histochemie, 4, 73-85 (1964).

16) J. F. A. MCMANus: Nature, 158, 202 (1946).

17) D. Mazia, P. A. Brewer and M. Alfert: Biol. Bull., 104, 57-67 (1953).

18) J. T. IRving: Arch. Oral. Biol., 8, 735-745 (1963).

19) M. H. MARks, R. S. BEAR and C. H. Blake: J. Exper. Zool., 111, $55-78$ (1949).

20) D. F. Travis: In "Biological Calcification. Cellulat and Molecular Aspects" (H. SChraer, ed.), 
Appleton-Century-Crofts, New York (1970).

21) K. Meyer: in "Bone Structure and Metabolism" (G.E.W. Wolstenholme and C. M. O'Conner, eds.), 65-74, J. \& A. Churchill Ltd., London (1956).

22) G. H. Bourne: The Biochemistry and Physiology of Bone, Academic Press, New York (1956).

23) K. M. Wilbur: in "Physiology of Mollusca" (K. M. Wilbur and C. M. Yonge, eds.), Vol. 1, 243-282 (1964).

24) S. Frtton-Jackson, R. D. Harkness, S. M. Partridge and G. R. Tristram: Structure and function of Connective Tissue, Butterworths, London (1964).

25) M. B. MATHEWS: Biol. Rev., 42, 499-551 (1967).

26. G. Quintarelli: The Chemical Physiology of Mucopolysaccharides, Boston Little, Brown and Company, J \& A. Churchill Ltd., London (1968).

27) I. BANGA and J. BALó: Biochem. J., 74, 388-393 (1960).

28) S. D. Schults-Haudt and N. EeghLarSen: Biochim. Biophys. Acta, 51, 560-566 (1961).

29) E. Havivi and D.S. Bernstern: Proc. soc. Exper. Biol. Med., 131, 1300-1304 (1969).

30) A. H. MelCher: Nature, 211, 593-595 (1966).

31) A. E. Sobel and M. Burger: Proc. Soc. Exper. Biol. Med., 87, 7-13 (1954).

32) S. Kobayashi: Internat. Rev. Cytol., 30, 257-371 (1971).

33) J. R. Gibins, L. G. Tilney and K. R. Porter: J. Cell Biol., 41, 201-226 (1969).

34) J. E. KINDRED: Biol. Bull., 46, 228-251 (1924). 
Plate I

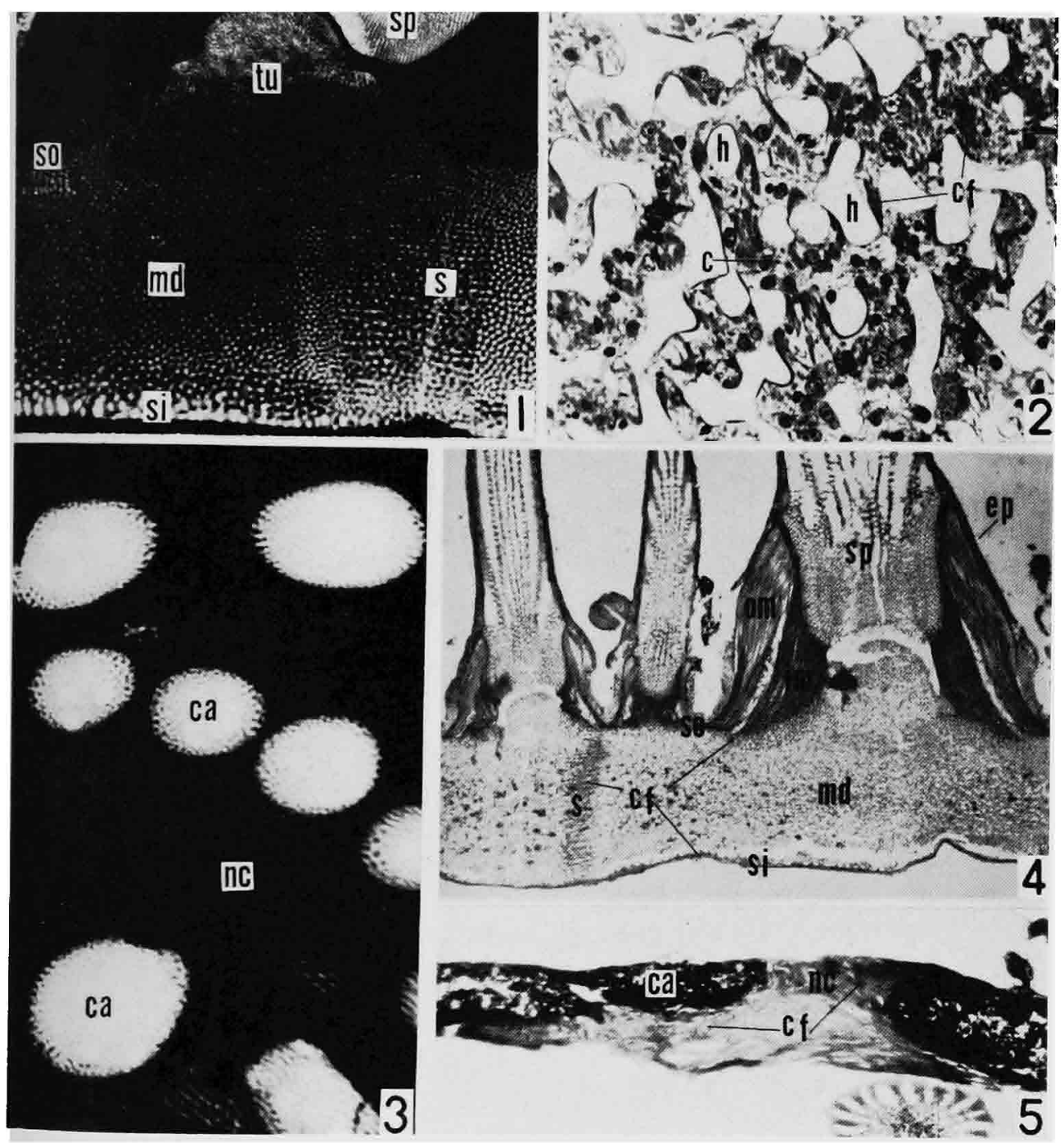


Plate II

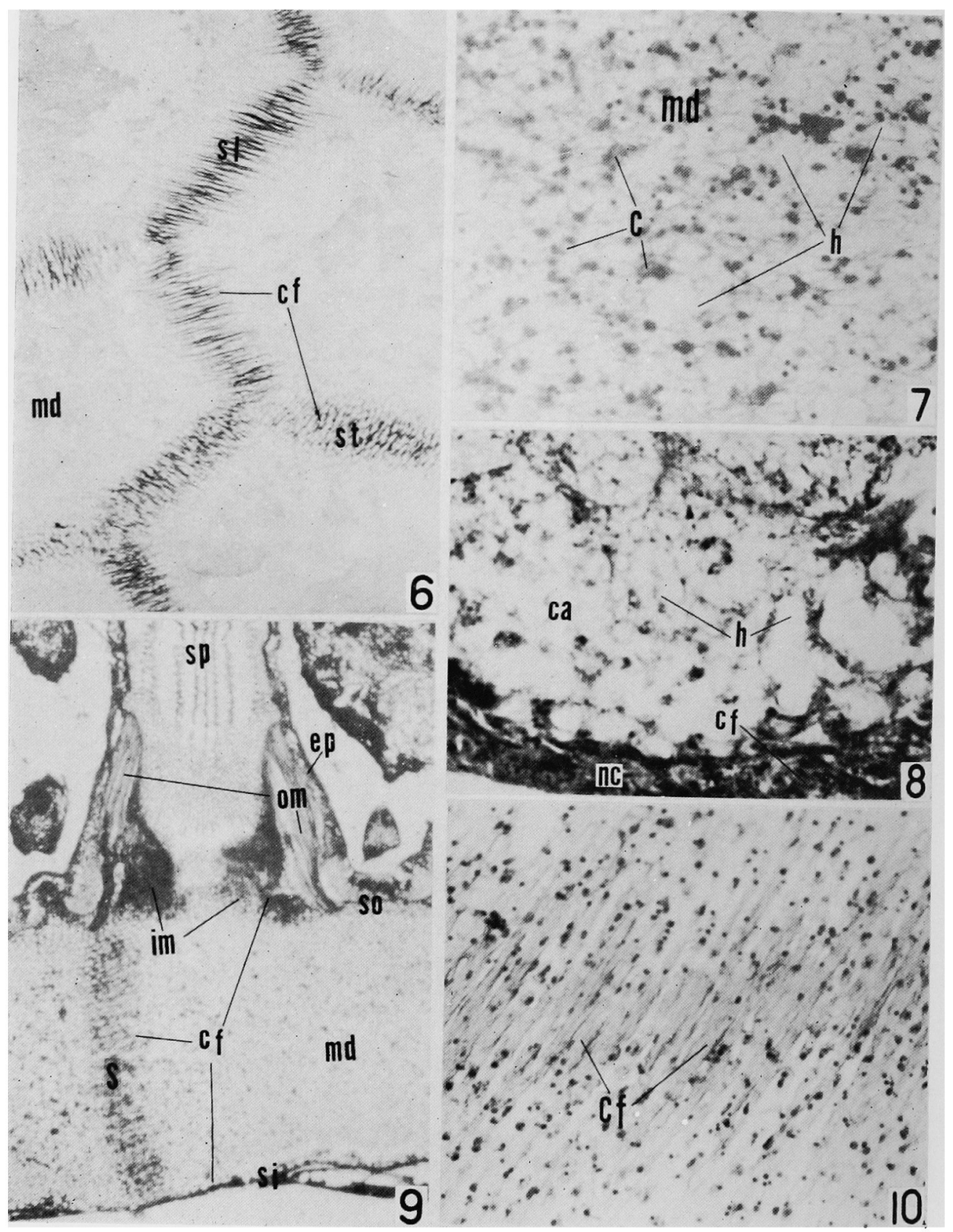


Plate III

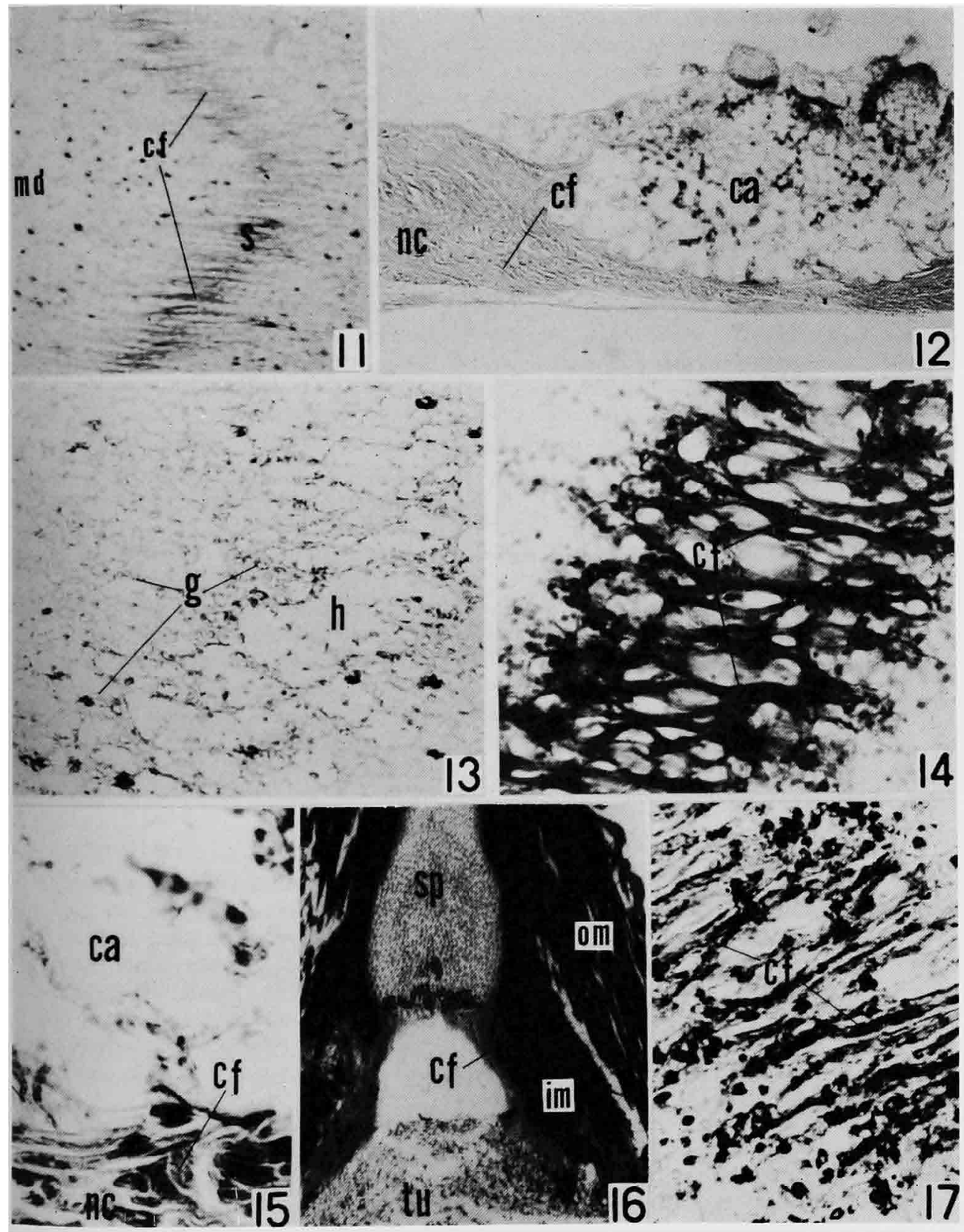




\section{Explanation of Plate I}

Fig. 1. Microradiography of a longitudinal ground section of the test plate showing the fenestrate structure of skeletal pillars $(\times 75)$. md: mid-portion of dermis; s: suture; si: inner surface of dermis; so: outer surface of dermis; sp: spine: tu; tubercle

Fig. 2. Epon section of the decalcified test plate through the sutural area (toluidine blue, $\times 800$ ). The parts corresponding to skeletal pillars are represented as "holes" (h) by decalcification. c: cellular elements; cf: collagen-like fibers

Fig. 3. Microradiography of the intact peristomial membrane showing round calcified "island" $(\times 40)$. ca: calcified area; nc: non-calcified connective tissue

Fig. 4. Longitudinal section of the decalcified test plate through the spine (sp) and the suture (s) (azan, $\times 65$ ). cf. collagen-like fibers; ep: epdermis; om: outer layer of spine muscle; im: inner layer of spine muscle; md: mid-portion of dermis; s: suture; si: inner surface of dermis; so; outer surface of dermis

Fig. 5. Longitudinal section of the peristomial membrane showing abundant collagen-like fibers (cf) around the calcified areas (ca) (von Kossa, $\times 60$ ). nc: non-calcified connective tissue

\section{Explanation of Plate II}

Fig. 6. Tangential section of the decalcified test plate showing the collagen-like fibers (cf) extending over both longitudinal (sl) and latitudinal (st) sutures (azan, $\times 90$ ). md: mid-portion of dermis

Fig. 7. Reticulous structure of the mid-portion of dermis (md) in which no collaken-like fibers are found (azan, $\times 400)$. c: cellular elements; h: "holes"

Fig. 8. Reticulous structure of the calcified area (ca) in the peristomial membrane (azan, $\times 350$ ). cf: collagen-like fibers; h: "holes"; nc: non-calcified connective tissue

Fig. 9. Moderate metachromasia found in the collagen-like fibers (cf) of the suture (s) and the inner layer of spine muscle (im) (toluidine blue, $\times 90$ ). ep: epidermis; md: midportion; om: outer layer of spine muscle; si: inner surface of dermis; so: outer surface of dermis; sp: spine

Fig. 10. Intense metachromasia appeared on the collagen-like fibers (cf) of the suture after the deamination for 24 hours (toluidine blue, $\times 350$ ).

\section{Explanation of Plate III}

Fig. 11. Tangential section of the test plate showing the sutural collagen-like fiber (cf) which are relatively intense to the PAS (PAS, $\times 120$ ). md: mid-portion; s: suture

Fig. 12. Longitudinal section of the peristomial membrane. The non-calcified connective tissue (nc) is relatively intense to the PAS, while the reticulous structure of thin organic substances of calcified areas (ca) is weak PAS-positive (PAS, $\times 240$ ). cf: collagenlike fibers

Fig. 13. Strong PAS-positive granules (g) found occasionally in the reticulous structure of the dermis. The PAS-positivity of these granules is not affected even after the deamination for 24 hours (PAS, $\times 175$ ). h: "holes"

Fig. 14. Sutural fibers intensely stained with $\mathrm{Hg}-\mathrm{BPB}(\times 700)$. cf: collagen-like fibers

Fig. 15. Reticulous structure of the calcified areas (ca) of the peristomial membrane showing a negative reaction for proteins $(\mathrm{Hg}-\mathrm{BPB}, \times 700)$. cf: collagen-like fibers; cn: noncalcified connective tissue

Fig. 16. Sudanophilic reaction found on the collagen-like fibers (cf) of the inner layer of the spine muscle $(\mathrm{im})$ and more intense reaction on the outer layer of the spine muscle (om) (sudan black B, 65 ). sp: spine muscle; tu: tubercle

Fig. 17. Collagen-like fibers (cf) of the suture showing a sudanophilia even after extracting lipids with hot pyridin for 24 hours (sudan black $B, \times 800$ ). 